\title{
Penerapan Model Pembelajaran Kooperatif dengan Media Audio Visual Berbasis Teknologi Untuk Meningkatkan Aktivitas dan Kemampuan Menyimak Mahasiswa
}

\author{
Resnani
}

Universitas Bengkulu resnani12@gmail.com

\begin{abstract}
This research aims to increase the activity and listening skill of students through a cooperative learning model of technology-based audio visual media at the course of language basic skills. The subjects were the students of PGSD in III B class academic year 2019/2020 which amounted to 40 students. The research instruments were observation sheets and test sheets of the listening skill. The observation data was analyzed by using the average score and the data of the listening capabilities analyzed by using of the average value and percentage. The results showed that (1) the implementation of cooperative learning models with technology-based visual audio media at the course of the language basic skills can increase the learning activity, (2) The application of cooperative learning model with technology-based audio visual media in the course of basic language skills can enhance the ability to listen of students who are infused with the ability to listen to the students each cycle increases. The average scor of the students 'listening skills at the first cycle is 78.05 with a detailed guidance of a kilacical study is $77.5 \%$ increased in the second cycle the average value of the student's listening capability is 83.25 with the classical guidance of the study is $92.5 \%$. It is thus concluded that the application of cooperative learning models with technology-based audio visuals can increase the activity and listening skill of IIIB students at the language Basic skills Lecture at the PGSD University of Bengkulu.
\end{abstract}

Keywords: cooperative learning, visual audio, listening skill

\begin{abstract}
Abstrak
Penelitian ini bertujuan untuk meningkatkan aktivitas dan keterampilan mendengarkan siswa melalui model pembelajaran kooperatif media audio visual berbasis teknologi pada kursus keterampilan dasar bahasa. Subjek penelitian adalah siswa PGSD kelas III B tahun akademik 2019/2020 yang berjumlah 40 siswa. Instrumen penelitian adalah lembar observasi dan lembar tes keterampilan menyimak. Data pengamatan dianalisis dengan menggunakan skor ratarata dan data kemampuan mendengarkan dianalisis dengan menggunakan nilai rata-rata dan persentase. Hasil penelitian menunjukkan bahwa (1) penerapan model pembelajaran kooperatif dengan media audio visual berbasis teknologi pada pembelajaran
\end{abstract}


keterampilan dasar bahasa dapat meningkatkan aktivitas pembelajaran, (2) Penerapan model pembelajaran kooperatif dengan media audio visual berbasis teknologi dalam kursus keterampilan bahasa dasar dapat meningkatkan kemampuan untuk mendengarkan siswa yang diresapi dengan kemampuan untuk mendengarkan siswa setiap siklus meningkat. Skor rata-rata keterampilan mendengarkan siswa pada siklus pertama adalah 78,05 dengan bimbingan rinci studi kilacical adalah $77,5 \%$ meningkat pada siklus kedua nilai rata-rata kemampuan mendengarkan siswa adalah 83,25 dengan bimbingan klasik penelitian ini adalah 92,5 \%. Dengan demikian disimpulkan bahwa penerapan model pembelajaran kooperatif dengan audio visual berbasis teknologi dapat meningkatkan aktivitas dan keterampilan menyimak siswa IIIB pada bahasa Ceramah keterampilan dasar di Universitas PGSD Bengkulu.

Kata kunci: pembelajaran kooperatif, audio visual, keterampilan mendengarkan

\section{Pendahuluan}

Di era glabalisasi saat ini, perkembangan teknologi banyak memberikan dampak dalam dunia pendidikan. Salah satu bentuk perkembangan tersebut adalah terciptanya media pembelajaran yang menarik, menyenangkan dan lebih bervariatif. Media pembelajaran yang menarik dapat menciptakan situasi pembelajaran yang aktif, kreatif dan menyenangkan. Melalui media, berbagai informasi/pesan dapat disalurkan, karena media merupakan sarana penyampai berbagai pesan dan berbagai informasi belajar. Secara umum media biasanya digunakan dalam proses pembelajaran. Berkaitan dengan hal ini, Abidin (2015: 255) menyatakan bahwa media pembelajaran biasanya digunakan oleh guru sebagai alat untuk meningkatkan pemahaman siswa terhadap konsep yang dipelajarinya.

Media pembelajaran biasanya digunakan oleh guru selama proses pembelajaran. Berkaitan dengan penggunaanya tersebut, maka media pembelajaran harus dipilih dan dicermati oleh guru dengan mempertimbangkan kesesuian media dengan tujuan pembelajaran dan bahan ajar serta karakteristik siswa. Selain itu, media juga harus rasional dan sesuai dengan kebutuhan siswa. Dalam konteks pembelajaran media bukan hanya dipandang sebagai alat bantu dalam pembelajaran, namun lebih luas dari itu. Sebagaimana diungkapkan oleh Gerlach dan Elly dalam Arsyad (2007: 3) yang menyatakan bahwa secara garis besar, media dapat dipahami sebagai manusia, materi atau kajadian yang mampu membentuk dan membangun kondisi peserta didik untuk dapat memperoleh pengetahuan dan keterampilan serta membangun sikap para peserta didik.

Berbagai media yang dapat digunakan dalam pembelajaran yang disesuai dengan karakteristik bahan ajar dan kebutuhan peserta didik. Salah satu media pembelajaran yang dapat digunakan sebagai alternatif dalam proses pembelajaran adalah media audio visual berbasis teknologi. Media audio visual adalah suatu media yang mengintegrasikan unsur visualisasi dan unsur audio dalam satu pemakaian sacara bersamaan dalam satu waktu dengan menggunakan alat teknologi. Sehubungan dengan ini, Heinz Kock dalam Wuryani (2008: 3) menyebutkan bahwa media audio visual adalah sebagai media yang memiliki unsur gambar dan unsur suara yang melibatkan unsur mata dan telinga yang dapat menciptakan kondisi dan suasana pembelajaran yang kondusif, menarik dan menyenangkan. Selanjutnya, media audio visual menurut Hermawan, dkk. (2007; 202) dapat juga disebut sebagai media projector yang mampu menampilkan berbagai unsur media seperti, teks, 
video, animasi, gambar, baik secara tepisah maupun yang dapat dikoneksikan dan dapat digabungkan dengan perangkat elektronik lainnya seperti komputer.

Bertemali dengan pendapat di atas, media audio visual yang digunakan dalam penelitian ini adalah media projector dengan perangkat kompudter yang disebut dengan media audio visual berbasis teknologi. Media ini digunakan untuk mengoptimalkan proses pembelajaran. Hal ini disebabkan oleh beberapa aspek antara lain; (1) media ini lebih mudah dikemas dalam proses pembelajaran; (2) lebih menarik untuk pembelajaran; dan (3) dapat di-edit (diperbaiki) setiap saat. Dengan pemanfaatan teknologi komputer tersebut, diharapkan bahwa media ini dapat dimanfaatkan untuk menyalurkan berbagai informasi terkait dengan bahan ajar sehingga peserta didik tertarik terhadap abahan ajar yang sedang dikaji.

Keterampilan menyimak merupakan salah satu pembelajaran yang membutuhkan pemahaman yang mendalam dan komprehensif. Terlebih menyimak merupakan kegiatan yang paling banyak dilakukan. Menyimak merupakan porsi terbesar dari waktu keseharian dalam kehidupan manusia. Hal ini sejalan dengan hasil penelitian yang dilakukan oleh Donald E.Bird terhadap mahasiswa "Stefhence Colelege Girls" dalam Saddhono (2012: 12) yang melaporkan bahwa di antara tiga keterampilan yang lainnya seperti berbicara, membaca, dan menulis, maka menyimak memiliki porsi yang terbesar yaitu $42 \%$. Sementara, berbicara $25 \%$, membaca $15 \%$, dan menulis $18 \%$. Hal ini mengisyaratkan bahwa pada umumnya, hanya sebagian kecil orang mendapat kesempatan untuk menjadi pembicara. Aktivitas ini biasanya siring ditemui dalam kegiatan komunikasi lisan.

Dalam kegiatan pembelajaran, para peserta didik harus mampu menyimak pesan yang diinformasikan/disampaikan oleh para guru atau dosen dengan cermat agar tujuan belajar dapat terwujud sesuai dengan harapan. Oleh sebab itu, alangkah tidak etisnya apabila ada anggapan yang menyatakan bahwa menyimak merupakan salah satu keterampilan yang paling mudah di antara empat keterampilan berbahasa lainnya. Sementara, Hermawan (2012: 30) berpendapat bahwa keterampilan menyimak adalah salah satu keterampilan yang kompleks yang memerlukan kecerdasan dan sikap mental yang aktif dalam mengasimilasi serta menerapkan setiap ide, atau gagasan. Keterampilan menyimak sangat memerlukan ketajaman perhatian, konsentrasi atau pemusatan perhatian terhadap suatu gagasan yang diterima.

Pernyataan tersebut di atas mengisyaratkan bahwa menyimak merupakan serangkaian proses yang selektif untuk menentukan informasi mana yang sangat dibutuhkan dari berbagai stimulus yang ada di sekitar kita. Aspek menyimak juga menjadi salah satu standar kompetensi yang harus dimiliki oleh mahasiswa. Salah satu standar kompetensi aspek menyimak yang tercantum adalah memahami wacana lisan melalui kegiatan mendengarkan berbagai informasi yang disimak dalam proses belajar.

Dalam kenyataannya, pembelajaran menyimak kurang diperhatikan karena pembelajaran ini dianggap sebagai hal yang sepele dan kurang penting untuk dipelajari. Sebagaimana diungkapkan oleh Abidin (2013: 97) bahwa kondisi pembelajaran menyimak saat ini sangat memprihatinkan karena masih dianggap pembelajaran yang kurang penting dibandingkan dengan tiga keterampilan yang lain. Para guru hanya menggunakan bahan ajar menyimak yang berasal dari buku teks siswa. Selain itu, rata-rata guru menyatakan bahwa aktivitas menyimak yang mereka lakukan dengan cara seperti itu karena kelangkaan media audio atau media audio visual yang tersedia di sekolah.

Berdasarkan hasil refleksi diri dan pengamatan teman sejawat ketika peneliti mengimplementasikan program penugasan dosen ke sekolah (PDS) ke dalam 
pembelajaran Keterampilan Dasar Berbahasa terdapat beberapa masalah dalam pembelajaran khususnya yang berkaitan dengan materi keterampilan menyimak. Permasalahan itu mencakup: (1) mahasiswa kurang paham dan menyadari tentang pentingnya keterampilan menyimak. (2) Penggunaan media pembelajaran masih minim.(3) Strategi pembelajaran menyimak kurang variatif. (4) Pembelajaran menyimak dilakukan secara menoton sehingga kurang memberdayakan mahasiswa untuk berperan aktif dan kreatif. Hal tersebut bisa memberi dampak terhadap rendahnya kemampuan menyimak para peserta didik.

Penelitian yang berkaitan dengan pembelajaran menyimak dengan media audio visual telah banyak dilakukan. Penelitian Gusmaidar (2016) menyimpulkan bahwa Keterampilan menyimak dongeng melalui media animasi audio visual mengalami peningkatan dari siklus sebelum pada setiap berikutnya. Keterampilan menyimak siswa siklus kesatu adalah 64,13 pada kategori cukup, meningkat pada siklus kedua menjadi 76,67 pada kategori baik. Selanjutnya, penelitian yang dilakukan oleh Yusantika, Suyatno, Furaidah (2018) menyimpulkan bahwa penggunaan media audio visual memberi pengaruh terhadap kemampuan menyimak siswa. Hal tersebut dapat dilihat dari perolehan hasil tes awal (pretest) dan hasil tes akhir (posttest) yaitu perolehan rata-rata pretest adalah 66,18 meningkat menjadi 79,92 pada saat posttest.

Demikian halnya dengan penelitian yang dilakukan oleh Nurani, Nugraha dan Sidik ((2018). Hasil penelitianya menunjukkan bahwa penggunaan media audio visual mampu meningkatkan kemampuan menyimak dongeng di era digital. Siswa lebih antusias dalam pembelajaran menyimak dongeng karena disampaikan dengan media pembelajaran yang menyenangkan dan menarik. Dari berbagai hasil penelitian tersebut, menunjukkan bahwa media audio visual dapat meningkatkan kemampuan menyimak siswa dan dapat memberikan pengaruh terhadap kemampuan menyimak para siswa.

Dalam proses pembelajaran, strategi yang biasa diterapkan pengajar agar mahasiswa dapat terlibat secara aktif adalah dengan melakukan diskusi dengan melibat seluruh mahasiswa yang berlangsung secara klasikal. Namun, aktivitas dan strategi ini belum efektif walaupun pengajar sudah memotivasi mahasiswa untuk berperan secara aktif. Pada situasi seperti ini,terlihat sebagian besar mahasiswa terpaku menjadi peserta yang aktif sebagai penonton. Sementara, diskusi dikuasai oleh beberapa mahasiswa. Sebagai solusi untuk mengatasi hal tersebut, maka pengajar perlu memilih strategi dan menciptakan suasana belajar di mana mahasiswa dapat bekerjasama, saling mendorong pembelajaran dan usaha akademis satu sama lainnya, dan dapat membantu teman satu kelompoknya dalam menyelesaikan suatu masalah, dan tugas untuk mencapai suatu tujuan.

Salah satu strategi pembelajaran yang menuntut mahasiswa untuk berperan aktif yang melibatkan partisipasi mahasiswa dalam satu kelompok kecil untuk saling berinteraksi berdasarkan kemampuannya adalah model pembelajaran kooperatif (cooperative learning). Rusman (2011: 202) menjelaskan bahwa pembelajaran kooperatif adalah bentuk pembelajaran dengan cara peserta didik belajar dan bekerja yang di dalamnya peserta didik terarah untuk bekerja dalam kelompok kecil untuk mencapai tujuan belajar bersama yang dilakukan secara berkolaboratif dalam kelompok kecil yang anggotanya terdiri dari 4-5 orang dengan struktur kelompok yang bersifat hetorogen.

Pada model ini, keberhasilan peserta didik akan tercapai jika setiap kelompoknya berhasil. Menurut Slavin (1995) dalam Trimurtini (2009) secara umum, pengaruh kerja kelompok adalah positif. Hasil penelitiannya menunjukkan bahwa $72 \%$ dari 68 
studi menunjukkan hasil belajar yang tinggi dalam bekerja secara kelompok yaitu terdapat pada kelompok kelompok eksperimen dibandingkan kelas kontrol.

Menurut Rusman (2011: 205), model pembelajaran kooperatif banyak digunakan di kalangan pendidikan. Hal ini berlandaskan atas hasil penelitian dari Slavin (1995) yang menjelaskan bahwa pertama, penerapan pembelajaran kooperatif dapat meningkatkan hasil belajar siswa, menghargai pendapat orang lain, dan mengembangkan sikap tenggang rasa. Kedua, pembelajaran kooperatif dapat mendorong siswa untuk berpikir kritis. Ketiga, pembelajaran kooperatif mampu meningkatkan kualitas pembelajaran dan dapat membantu siswa dalam memecahkan masalah yang dihadapinya.

Berdasarkan permasalahan yang di atas, maka penerapan model pembelajaran kooperatif dengan media audio visual berbasis teknologi pada perkuliahan Keterampilan Dasar Berbahasa memiliki fungsi dan peran yang penting bagi terwujudnya pembelajaran yang berkualitas. Oleh karena itu, perlu dilakukan penelitian yang mengkaji tentang bagaiman penerapan pembelajaran kooperatif dengan media audio visual berbasis teknologi dapat meningkatan aktivitas dan kemampuan menyimak mahasiswa pada perkuliahan Keterampilan Dasar Berbahasa di PGSD FKIP Unib.

\section{Metode}

Metode yang digunakan dalam penelitian ini adalah penelitian tindakan kelas (PTK), yaitu penelitian yang berdasarkan hasil refleksi diri dan permasalahan yang ditemukan di dalam proses pembelajaran. Prosedur penelitian ini mengikuti prinsip dasar yang berlaku dalam penelitian tindakan kelas. Desain penelitian tindakan kelas meliputi empat aspek yang merupakan bentuk daur ulang atau siklus yang dimulai dari tahap perencanaan, pelaksanaan tindakan, pengamatan, dan refleksi (Sudarsono, 2007).

Hal senada diungkapkan Sukayati (2008: 17) yang menyatakan bahwa salah satu desain untuk melaksanakan penelitian tindakan kelas (PTK) dapat menggunakan model Mc Taggart dan prosedur pelaksanaan PTK yang mencakup: (a) perencanaan, (b) tindakan, (c) pengamatan, dan (d) refleksi. Keempat tahapan ini dilaksanakan secara daur ulang atau berulang-ulang hingga mencapai hasil yang diharapkan.

Penelitian ini dilakukan pada mahasiswa semester III kelas B Prodi PGSD S1 FKIP Unib Tahun Akademik 2019/2020. Jumlah mahasiswa sebanyak 40 orang yang terdiri dari 8 laki-laki dan 32 perempuan. Penelitian ini dilakukan untuk memperbaiki pembelajaran keterampilan Dasar Berbahasa dengan materi Keterampilan Menyimak. Ada dua bentuk aktivitas pembelajaran yang berkaitan dengan materi menyimak yaitu membahas berbagai konsep/teori menyimak dan melakukan aktivitas menyimak untuk memahami bahan simakan dengan menyimak rekaman bahan simakan melalui audio visual berbasis teknologi.

\section{Hasil}

Hasil penelitian yang dideskripsikan mencakup: aktivitas pembelajaran dan kamampuan menyimak mahasiswa melalui penerapan model pembelajaran kooperatif dengan media audio visual berbasis teknologi. Kegiatan pembelajaran menyimak pada perkuliahan Ketrampilan Dasar Berbahasa (KDB) terdiri dari dua kegiatan yaitu (1) membahas tentang konsep-konsep atau berbagai materi yang terkait dengan keterampilan menyimak, (2) praktik memahami bahan simakan. Hasil pnelitian ini disajikan berdasarkan proses tindakan dan hasil tindakan yang 
telah dilaksanakan dalam dua siklus. Masing-masing siklus dilaksanakan sebanyak dua kali pertemuan.

a. Deskripsi Data Aktivitas Pembelajaran

Aktivitas mahasiswa dalam pembelajaran menyimak dengan menerapkan model pembelajaran kooperatif dengan media audio visual berbasis teknologi pada siklus pertama masih belum optimal. Hal ini disebabkan masih terdapat mahasiswa yang belum aktif dan serius mengikuti pembelajaran, ketika diskusi sedang berlangsung. Dari 40 mahasiswa yang dibagi ke dalam 8 kelompok, hanya 6 kelompok (75\%) yang aktif dan serius dalam proses pembelajaran. Selanjutnya, dari hasil lembar observasi aktivitas mahasiswa menunjukkan bahwa nilai rata-rata aktivitas belajar mahasiswa adalah 30 dari skor maksimal 45. Angka tersebut termasuk pada kriteria cukup. Untuk hasil observasi aktivitas dosen menunjukkan bahwa nilai rata-rata aktivitas dosen adalah 33 dari skor maksimal 45. Angka tersebut termasuk pada kriteria cukup.

Pada siklus kedua, baik aktivitas mahasiswa maupun aktivitas dosen, menunjukkan hasil pada kategori baik. Aktivitas belajar dalam kelompok menunjukkan persentase yang meningkat yaitu dari 6 kelompok pada siklus pertama menjadi 8 kelompok (100\%). Dari hasil analisis lembar akvitas mahasiswa pada siklus II ini menunjukan nilai rata-rata skor adalah meningkat yaitu dari skor 30 menjadi 40 dari skor maksimak 45 dengan kreteria baik. Demikian juga nilai rata-rata skor aktivitas dosen juga meningkat yaitu dari skor 33 menjadi menjadi 42 dari skor maksimal 45 dengan kreteria baik.

\section{b. Deskripsi Data Kemampuan Menyimak Mahasiswa}

Pada siklus 1, kemampuan menyimak mahasiswa pada perkuliahan Keterampilan Dasar Berbahasa belum berhasil dengan baik. Tingkat pencapaian kemampuan menyimak mahasiswa secara individu mendapat nilai rata-rata sebesar 78,05 dengan ketuntasan belajar secara klasikal adalah 77.5\%. Hasil tersebut menunjukkan bahwa ketuntasan belajar mahasiswa belum memperoleh hasil sesuai dengan target yang ditentukan yaitu $85 \%$ mahasiswa mendapat nilai rata-rata 80 . Dengan demikian, masih perlu perbaikan tindakan pada siklus berikutnya.

Pada siklus II, kemampuan menyimak mahasiswa pada perkuliahan Keterampilan Dasar Berbahasa sudah berhasil dengan baik. Tingkat pencapaian kemampuan mahasiswa secara individu memperoleh nilai dengan rata-rata sebesar 83,25 dengan ketuntasan secara klasikal adalah 92,5\%. Hasil tersebut mengisyaratkan bahwa nilai rata-rata mahasiswa dan persentase ketuntasan secara klasikal sudah dinyatakan berhasil/tuntas. Dengan demikian, penerapan model pembelajaran kooperatif dengan medi audio nvisual berbasis teknologi pada pembelajaran KDB dapat meningkatkan kemampuan menyimak mahasiswa semester III kelas B di PGSD FKIP Universitas Bengkulu.

\section{Pembahasan}

Berdasarkan analisis data diperoleh informasi bahwa hasil observasi aktivitas pembelajaran menyimak, baik aktivitas mahasiswa maupun aktivitas dosen pada perkuliahan Keterampilan Dasar Berbahasa pada siklus pertma masih belum optimal. Di mana, 40 mahasiswa yang dibagi ke dalam 8 kelompok, hanya 6 kelompok (75\%) yang aktif dan antusias dalam proses pembelajaran. Hal ini disebabkan masih terdapat 2 kelompok yang tidak menunjukkan peran sertanya atau kerja sama yang baik dan aktif dalam kelompok untuk mencapai keberhasilan yang optimal. Sementara, Rusman (2011: 207) menyatakan bahwa keberhasilan dalam pembelajaran kooperatif (cooperatif learning) ditentukan keberhasilan secara kelompok. Keberhasilan pembelajaran tidak akan tercapai secara optimal tanpa kerja sama yang baik dalam kelompok, 
Demikian juga hasil aktivitas pembelajaran yang masih termasuk pada kategori cukup. Kondisi ini terjadi karena ada beberapa hal. Pertama; aktivitas pembelajaran didominasi segelintir mahasiswa yang aktif dan antusis bekerja sama dalam kelompok. Kedua; masih terdapat beberapa kelompok yang dalam kegiatannya tidak saling membantu untuk memperjuangkan keberhasilan kelompok. Ketiga, kelas terkesan pasif dan kurang kondusif karena forum diskusi dalam kelompok kecil seperti tanya jawab belum berlansung secara optimal. Ketiga, beberapa mahasiswa hanya bergantung pada mahasiswa yang aktif saja dalam satu kelompok. Selain itu, dosen kurang memotivasi mahasiswa untuk menyalurkan idenya ke dalam forum diskusi dalam kelompok belajarnya.

Dengan demikian, aktivitas dan kreativitas yang diharapkan dalam proses pembelajaran kooperatif yang menghendaki adanya interaksi antaranggota dalam kelompok belum berjalan secara seimbang. Sehingga, pembelajaran yang aktif, kreatif dan menyenangkan belum tercipta secara optimal. Demikian juga, kemampuan mahasiswa dalam menyimak belum mencapai ketuntasan yang diharapkan karena pembelajaran menyimak masih dilaksanakan secara menoton. Hal ini sejalan dengan pendapat Abidin (2013: 99) yang menjelaskan bahwa pembelajaran menyimak yang dilakukan secara menoton tidak akan membuat para siswa aktif dan kreatif dalam mengikuti kegiatan menyimak.

Berdasarkan hasil refleksi pada sikulus pertama, maka dilakukan perbaikan pada siklus kedua untuk memperbaikan aktivitas pembelajaran tersebut. Perbaikan yang dilakukan pada siklus ini adalah (1) memotivasi mahasiswa agar lebih aktif dan kreatif dalam memberi tanggapan terhadap hasil penyajian materi yang disampaikan pada setiap kelompok, (2) mendorong mahasiswa untuk bekerjasama secara maksimak dan bertanggung jawab akan keberhasilan belajar semua kelompok. (3) memaksimalkan penggunaan media agar mahasiswa lebih antusias dalam menyimak, sehingga target capaian pembelajaran dapat terwujud sesuai dengan tujuan yang diharapkan.

Dengan merujuk kepada skor rata-rata aktivitas mahasiswa dan dosen, serta hasil tes kemampuan mahasiswa dalam menyimak pada siklus kedua ini, maka baik aktivitas pembelajaran maupun kemampuan menyimak mahasiswa sudah mencapai target yang diharapkan. Dengan demikian, perbaikan hanya dilakukan sampai pada siklus kedua. Terjadinya peningkatan aktivitas maupun kemampuan menyimak mahasisawa pada perkuliahan keterampilan Dasar Berbahasa ini tentunya tidak terlepas dari karakteristik dan tujuan dari model pembelajaran maupun media audio visual yang digunakan dalam pembelajaran. Hal ini sejalan dengan pendapat yang dikemukakan oleh Rusman (2013: 209) yang menyatakan bahwa model pembelajaran kooperatif dikembangkan dan digunakan dalam pembelajaran, paling tidak untuk mencapai tiga tujuan pembelajaran yakni: hasil belajar akademik, penerimaan keragaman, dan keterampilan sosial.

Demikian juga media audio visual, banyak memberi pengaruh terhadap pembelajaran. Yusantika, dkk. (2018) mengungkapkan hasil penelitian tentang media audio visual yang dilakukan oleh Kausar (2013) terhadap mahasiswa di University Islamabad. Hasil penelitiannya menunjukkan bahwa bahwa sebanyak 91\% mahasiswa memilih dan menentukan untuk menggunakan audio visual dalam mempelajari bahasa. Melalui media audio visual dapat membantu mahasiswa untuk mengingat kata-kata baru dan belajar tentang sesuatu yang belum pernah mereka pelajari. 


\section{Simpulan}

Berdasarkan analisis data dan pembahasan, maka hasil penelitian ini dapat disimpulkan sebagai berikut.

1. Penerapan model cooperatif learning dengan media audio visual berbasis teknologi pada perkuliahan Keterampilan Dasar Berbahasa dapat meningkatkan aktivitas pembelajaran baik aktivitas mahasiswa maupun aktivitas dosen. Hal ini terlihat dari peningkatan skor rata-rata observasi setiap siklusnya. Hasil observasi mahasiswa pada siklus pertama skor rata-rata yang diperoleh adalah 30 dengan kriteria cukup meningkat pada siklus kedua dengan skor rata-rata yang diperoleh adalah 40 dengan kriteria baik. Hasil observasi dosen pada siklus pertama skor rata-rata adalah 33 dengan kategori cukup meningkat pada siklus kedua dengan skor rata-rata adalah 42 dengan kriteriai baik.

2. Penerapan model kooperatif learning pada perkuliahyan Keterampilan Dasar Berbahasa dapat meningkatkan kemampuan menyimak mahasiswa. Hal ini terlihat dari kemampuan menyimak mahasiswa meningkat setiap siklusnya. Kemampuan menyimak mahasiswa pada siklus I nilai rata-rata adalah 78,5 dengan persentase ketuntasan adalah $77,05 \%$ meningkat pada siklus II dengan nilai rata-rata adalah 83,25 dengan persentase 92,5\%. Dengan demikian dapat disimpulkanh bahwa penerapan model cooperatif learning dengan media audio visual berbasis teknologi pada perkuliahan Keterampilan Dasar Berbahasa dapat meningkatkan aktivitas pembelajaran dan kemampuan menyimak mahasiswa semester III kelas B Tahun Akademik 2019/2020.

\section{Referensi}

Abidin, Y. 2013. Pembelajaran Bahasa Berbasis Pendidikan Karakter. Bandung: PT Refika Aditama

Abidin, Y. 2014. Desain Sistem Pembelajaran dalam Konteks Kurikulum 2013. Bandung: PT Refika Aditama.

Abidin, Y. 2015. Pembelajaran Multiliterasi. Bandung: PT Refika Aditama.

Arsyad, A. 2007. Media Pembelajaran. Jakarta: PT. Raja Grafindo Persada.

Gusmaidar. 2016. Peningkatan Keterampilan Menyimak Dongeng dengan Menggunakan Media Animasi Audio Visual Melalui Metode Think Pairs Share Pada Siswa. Jurnal Pendidikan Guru Indonesia.

Hernawan, H., A. dkk. 2007. Media Pembelajaran Sekolah Dasar. Bandung: UPI PRESS.

Hermawan, H. 2012. Menyimak: Keterampilan Berkomunikasi yang Terabaikan. Yogyakarta: Graha Ilmu.

Rusman. 2011. Model-model Pembelajaran Mengembangkan Profesional Guru.Bandung: PT.Raja Grafindo Persada.

Saddhono, K. 2012. Meningkatkan Keterampilan Berbahasa Indonesia (Teori dan Aplikasi). Bandung: Karya Putra Darwati.

Sudarsono, FX. 1997. Pedoman Pelaksanaan Penelitian Tindakan Kelas (PTK). Rencana, Desaian, dan Implentasi. Yogyakarta: Derjen Dikti Depdikbud. 
Sukayati. 2008. Penelitian Tindakan Kelas. Yogyakarta: Pusat Pengembangan dan Pemberdayaan Pendidik dan Tenaga Kependidikan Matematika.

Wardani. I.,G, IG.A.K. 2002. Penelitinan Tindakan Kelas. Jakarta: Pusat Penerbitan Universitas Terbuka.

Wuryani, T. 2008. Media Pembelajaran. [on line]. Tersedia: files. wordpress.com/2008 media pembelajaran.ppt. [20 April 2013]. 